\title{
Vertical Cylindrical structures in Danish Quaternary (Weichselian) glaciofluvial deposits: their description and genesis
}

\author{
JENS PETER JENSEN AND JOHN MILLER
}

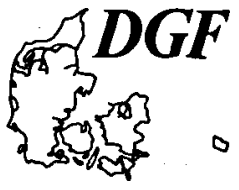

Jensen, J. P. \& Miller, J.: Vertical Cylindrical structures in Danish Quaternary (Weichselian) glaciofluvial deposits: their description and genesis.Bull. geol. Soc. Denmark, Vol. 38, pp. 59-67, Copenhagen, April 25th, 1990. https://doi. org/10. 37570/bgsd-1990-38-06

\begin{abstract}
Two examples of vertical cylindrical structures are described from the Danish Quaternary (Weichselian) glaciofluvial deposits. The structures are interpreted as water escape structures. A three bed model is suggested: i) lower mobilised bed, ii) impermeable layer and iii) a penetrated topbed. It is suggested that the model can be applied to other occurrences in different sedimentary environments.
\end{abstract}

Jens Peter Jensen, Miljøkontrollen, Stormgade 20, 1555 København V. John Miller, Fredens Plads 3, 2900 Charlottenlund. March 3rd, 1989.

\section{Introduction}

Vertical cylindrical structures of varying size and associated with a range of sedimentary environments have been described from strata of ages from Cambrian to the Quaternary (e.g. Bromley et. el., 1975, Dionne and Laverdiere, 1972. Gabelman, 1955, Gulinck, 1949 and Schlee, 1963). Their origin has in many cases remained enigmatic although several attempts have been made to suggest possible origins (Dionne and Laverdiere, 1972, Gabelman, 1955). In the course of studies of Quaternary glaciofluvial deposits in Denmark two examples of vertical cylindrical structures have been observed by the authors, one structure being in esker deposits at Spanager and the other in sandur fan deposits at Lynge (fig. 1). These structures will be described in their sedimentary settings and an attempt will be made to suggest a mechanism for their origin.

\section{Vertical cylindrical structures in the literature}

As the name suggests vertical cylindrical structures have a circular to oval cross section and are orientated so that they usually are perpendicular to horizontal bedding planes or lamination of enclosing sediments.
In size structures refered to in the literature as cylindrical structures normally vary in a diameter from a few centimeters up to about 200 centimeters and observed heights from about 1 to 6 meters (Dionne and Laverdiere, 1972 and Hawley and Hart, 1934) although exceptionally large structures with diameters up to 50 meters and heights of more than 80 have been noted by Schlee (1963).

The contact to the enclosing sediments has generally been observed to be sharp with little or no disturbance of the deposits outside the structures.

Internal features are more varied, in some cases being massive, structureless fills whilst in others well developed concentric lamination or conical bedding reminiscent of the cone-in-cone structures may be developed. The lithology of the cylinders may or may not be comparable to the enclosing sediments. Cylindrical structures have been observed in deposits of a range of sedimentary environments from shallow marine (Hawley and Hart, 1934) through coastal mud flats (Gabelman, 1955) and tidal delta (Bromley et al, 1975) to glaciodeltaic (Dionne and Laverdiere, 1972) and glaciofluvial (Dionne, 1973). Depending on the character of the individual cylindrical structure, the sedimentary environment and lithological setting, speculative interpretations of origin have been made. Gabelman (1955) and Dionne and Laverdiere (1972) have pre- 

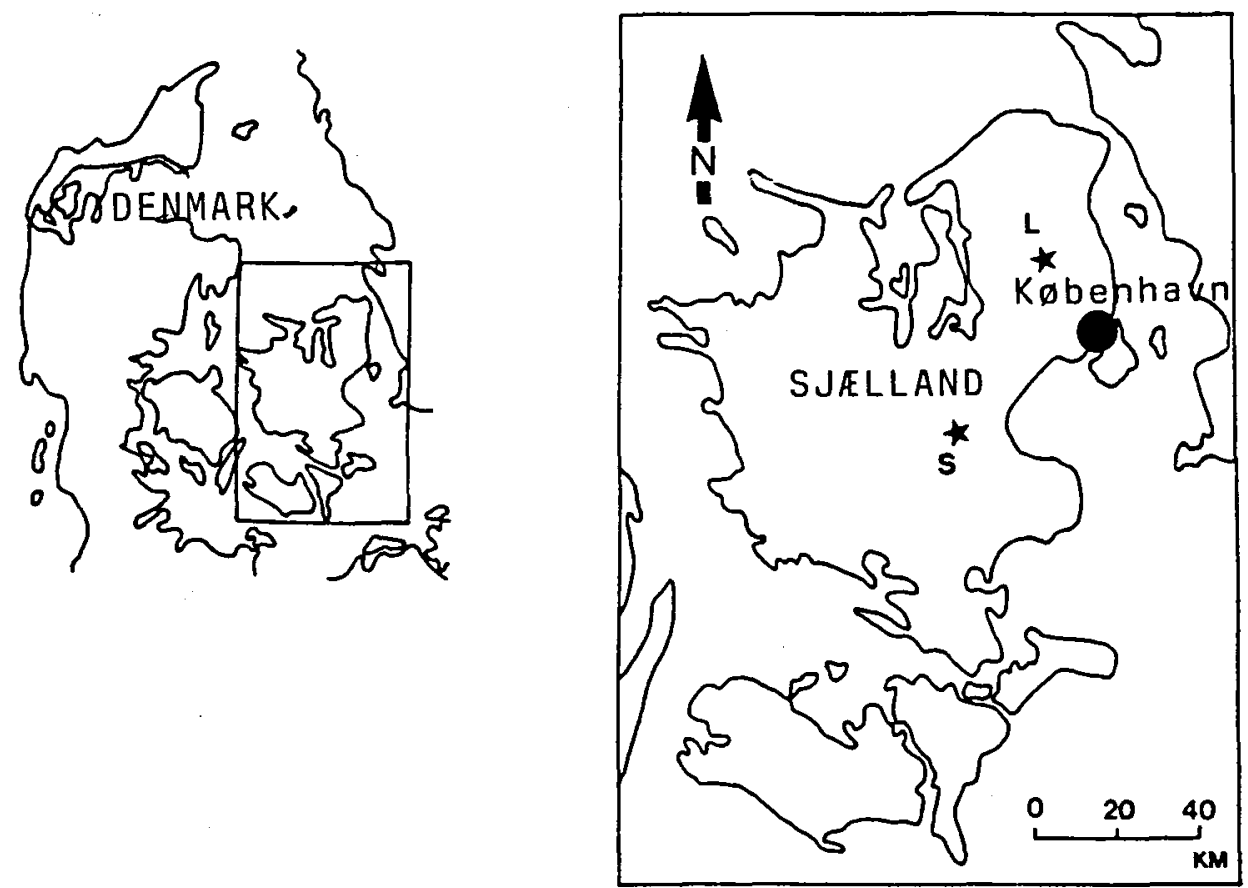

Fig. 1: Location-map. L denotes the Lynge location and S marks the Spananger location.

sented lists of possible origins such as ascending sub-surface springs, filling of cavities and stationary whirlpools. It is possible that the enigmatic origin of many of these structures can be clarified by reference to smaller scale fluidisation features such as dish and small scale pillars (Lowe and LoPiccolo, 1974, Lowe, 1975).

\section{Pre-Quaternary examples}

The earliest described example of vertical cylindrical structures are from the Potsdam sandstone (Upper Cambrian) of Ontario (Kavanaugh, 1889). Considering the age of the sandstone the suggestion made by Kavanaugh that these are concretions formed around a tree trunk was unrealistic. Several authors have reported on the Potsdam structures including Hawley and Hart (1934) who came to the conclusion after laboratory experiments that the structures were formed at sites af former sub-marine springs by groundwater ascending through the unconsolidated sediments. The mechanism of ascending waters has also been applied by Gabelman (1955) to explain cylindrical structures in assumed Permian deposits of the East Brush Creek area of Colorado and by Arai (1959) who observed several structures in Miocene deposits in Japan. In Paleocene sandstones of Patagonia, Simpson $(1935,1936)$ found cylindrical structures which he explained as either fillings of cavities in older bed or by injectios from above or below. Structures of considerable size in Jurassic deposits of New Mexico by Schlee (1963) are explained by " foundering of partially consolidated sand into underlying silts and clays".

In sands or silts of Landenian (Upper Palaocene) in Belgium, Gulinck (1949) described a cylindrical structure which he attributed to collapse of a cavity in the underlying chalk.

\section{Quaternary examples}

Three references to Quaternary vertical cylindrical structures have been found in the literature (Dionne and Laverdiere, 1972, Dionne, 1973 and Bromley et. al., 1975).

From glaciodeltaic deposits at Staint-Jerome near Montreal, Dionne and Laverdiere, (1972) 


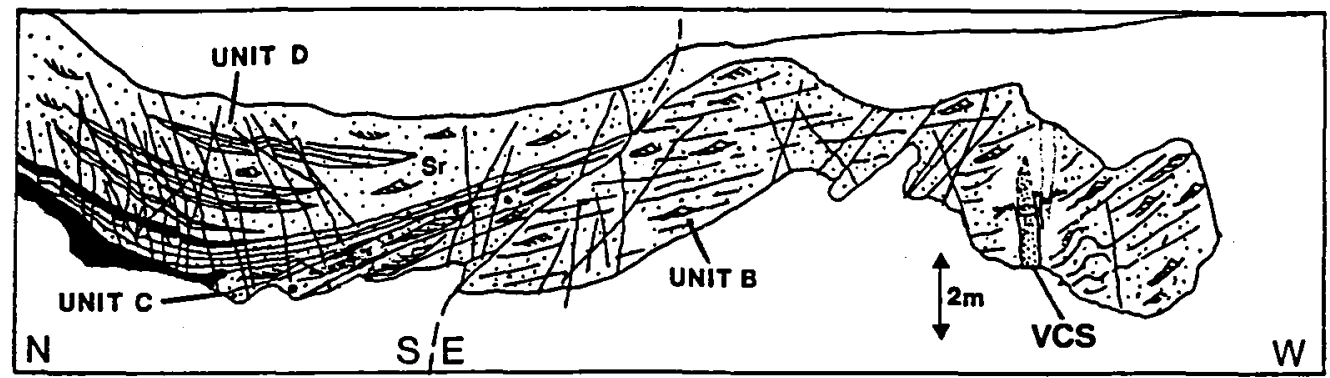

Fig. 2: The esker profile of Spanager. Unit B: Small scale crossbedded pointbar sand, with major accretionary planes (epsilon crossbedding). Unit C: Dune crossbedded sand and gravel (meander channel botttom) and suspension fines and sand (meander abondonment). Unit D: Small scale crossbedded sand with minor channels (reactivated meander channel).

Note the vertical cylindrical structure (vcs) and the numerous conjugated faults.

have described a structure 152,5 centimeters in height and 24 centimeters (base) to 35 centimeters (top) in diameter. Internally beds of me-

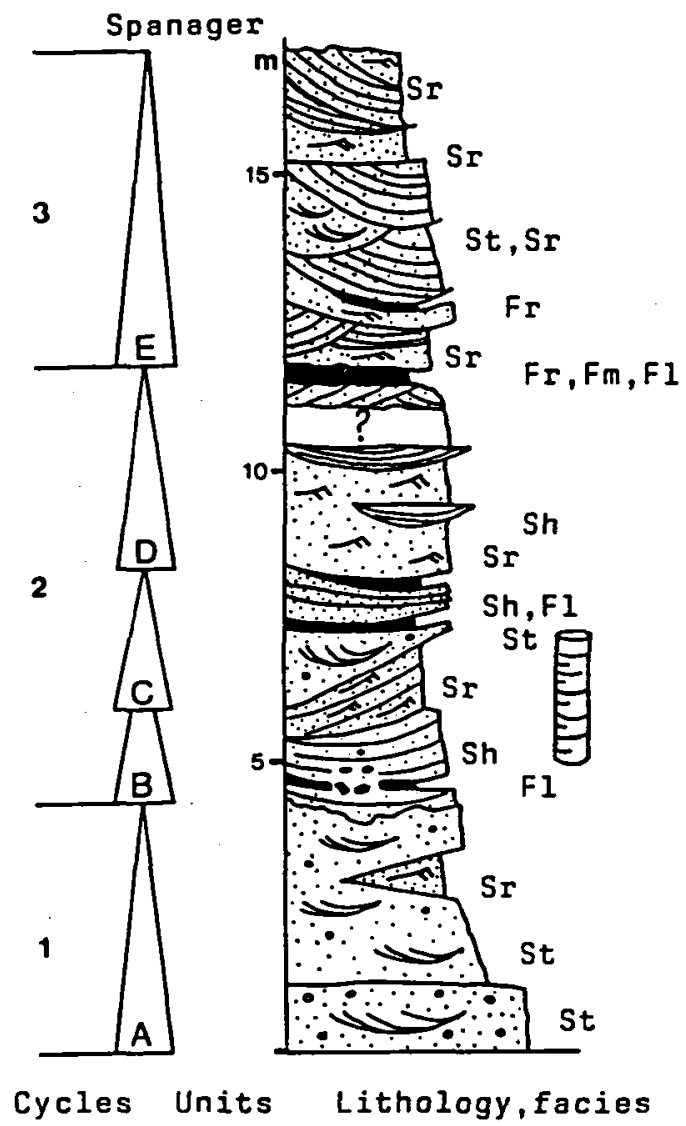

dium sand and silt formed conical structures in vertical section and concentric circular structures in the horizontal section. Contacts to the sur-

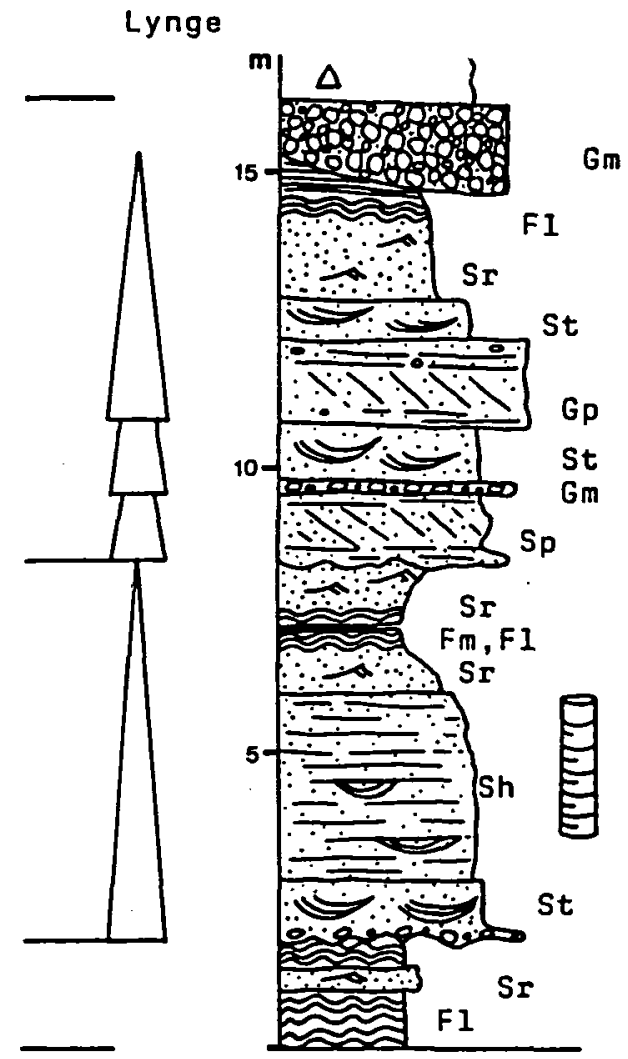

Units

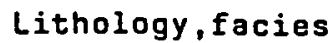

Fig. 3: Spanager- and Lynge logs.

Facies code after Miall $(1977,1978)$. G marks gravelly facies, $\mathbf{S}$ sandy facies and $\mathrm{F}$ denotes fines. The suffix $\mathrm{r}$ denotes ripple crossbedding, $t$ large scale trough crossbedding, $h$ respectively 1 denotes horisontally bedding (sand) and lamination (fines), $m$ means massive appearence/no structures and $\mathrm{p}$ marks large scale planar crossbedding.

The Spanager log show 5 fining upwards sedimentary units, which constitute 3 eskerine annual discharge cycles ("megavarves"). The Lynge log show 2 major fining upwards units, which constitute one large coarsening upwards interlobate sandur-fan unit. The position of the vertical cylindrical structures (VCS) are shown by the cylinder signature. 


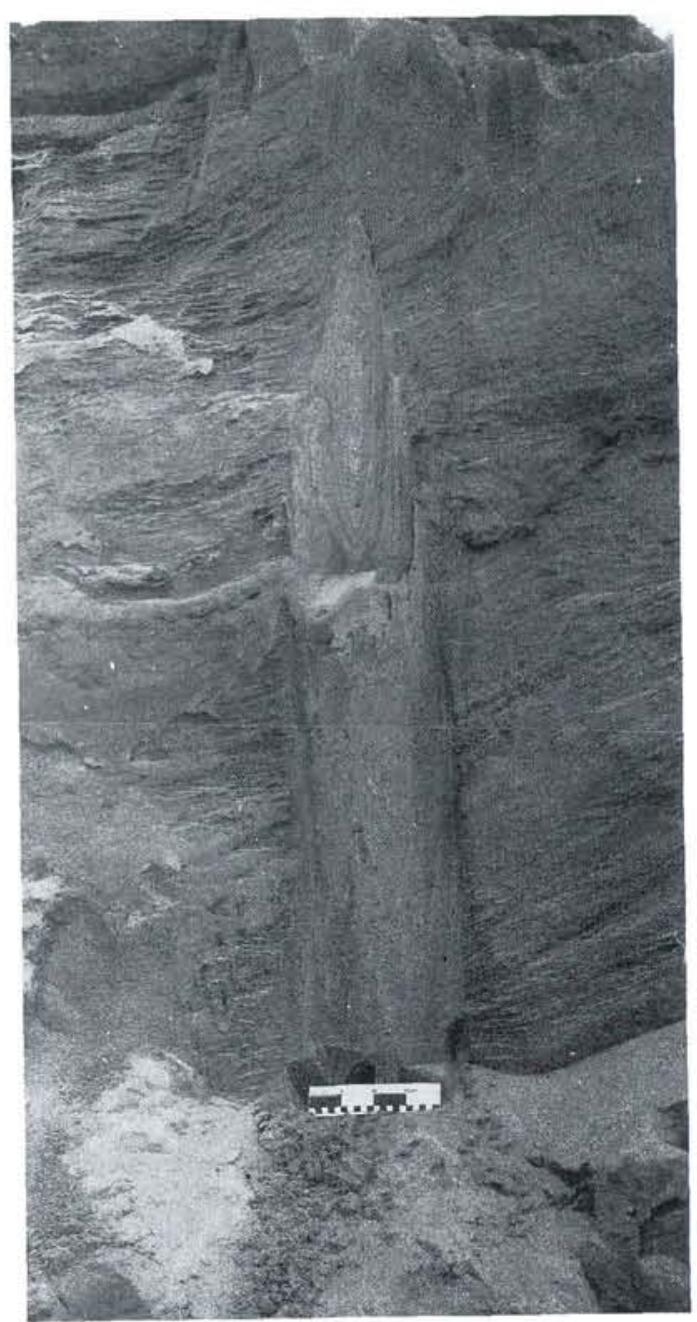

Fig. 4: The exposed length of the Spanager Structure. The small units of the scale are centimeters. The length of the scale is 20 centimeters.

rounding deposits was sharp although micro faults occured towards the base of the structure. The favoured genetic interpretation was that this structure was formed by a stationary whirlpool (Dionne and Laverdiere, 1972).

Dionne (1973) describes a series of six cylindrical structures from Arthabaska, Quebec, varying in diameter from 3 centimeters to 20 centimeters and minimum height from 50 to 225 centimeters. Sharp contacts to surrounding sediments and concentric laminations were observed. Here the preferred origin is that water ascending to surface springs formed these structures (Dionne, 1973).

On reexamination of the Staint-Jerome locality two new structures had been discovered and Dionne (1973) suggested a reinterpretation along the lines of ascending spring waters for three structures at that site.

From tidal deltaic deposits af North Carolina, Curran and Frey (in Bromley et, al., 1975) have described two types of vertical cylindrical structures. Six structures ranging in height from 1.2 meters to 3 meters and 10 to 24 centimeters in diameter with well developed V- to U-shaped internal lamination were, with considerable scepticism, interpreted as biogenic escape structures possibly of burrowing sea aneamones (Bromley et. al., 1975). Larger cylinders with minimum height of 2.5 meters and maximum diameter of 37 centimeters lacked well defined internal structures. Biogenic and physical origins are discussed but the structures remained enigmatic (Bromley et. al., 1975).

To these examples of Quaternary cylindrical structures are now added two examples from the Quaternary of Denmark presented in this paper.

\section{The Spanager structure}

\section{Stratigraphy}

The Spanager vertical cylindrical structure was found in the Køge Esker which is situated in the eastern part of Sjælland, Denmark, (Fig. 1). The Køge Esker was probably deposited by an oscilating ice of Weichselian age from the east (Main Weichselian Ice advance, c.f. Houmark-Nielsen, 1987). North-vergent folds and some conjugated faults are interpreted as being generated by the later overiding Weichselian ice which came from a southern direction (Jensen, 1985) and presumeably corresponds to the youngest Weichselian ice advance: the Bælthav Readvance of the Young Baltic glaciation.

\section{Setting}

The sandy Spanager Esker sequence has been divided into 5 sedimentary fining upwards units, the units A, B, C, D, and E (Fig. 2 and fig. 3)

Unit $\mathrm{A}$ is considered deposited by migrating dunes and ripples. 


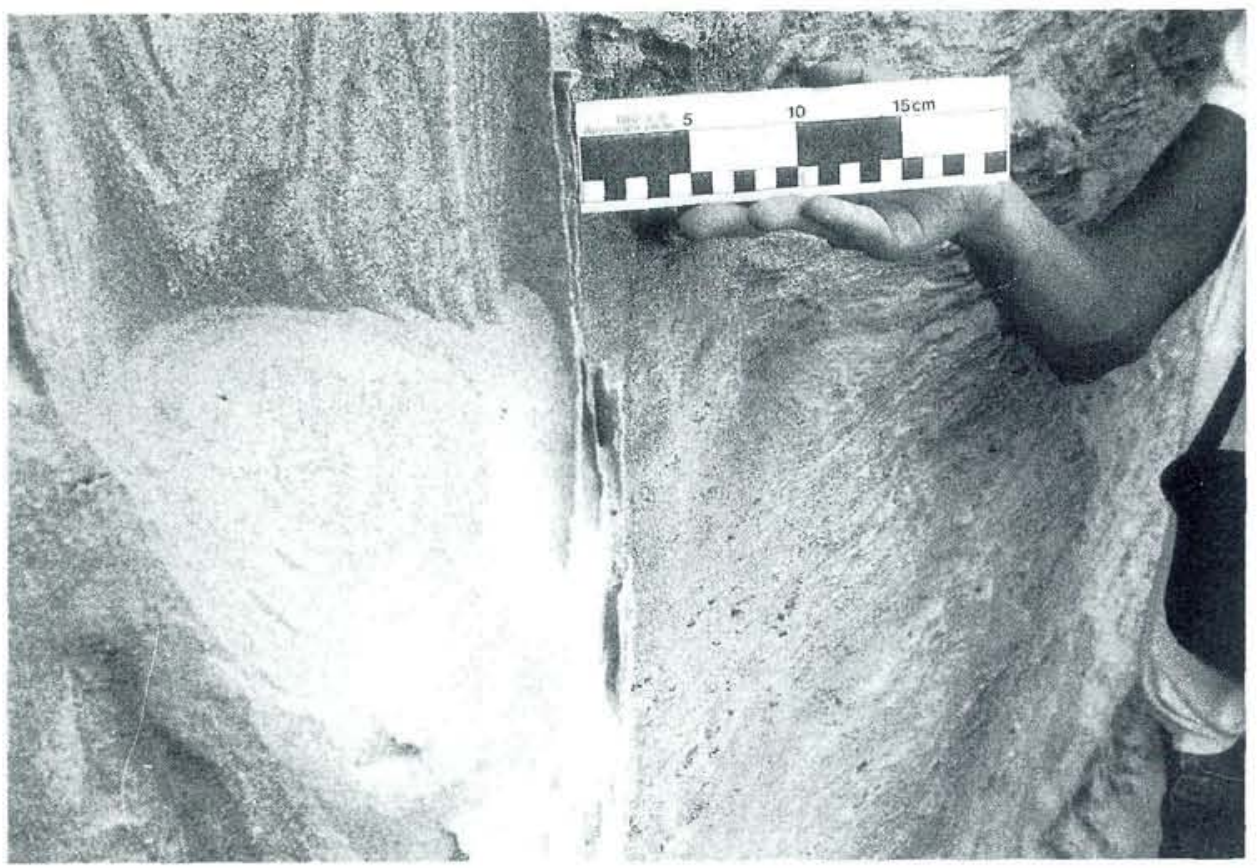

Fig. 5a: Detail of the Spanager structure showing the cylindrical laminae.

The vertical cylindrical structure was found in the overlying unit B. (See figs. 2 and 3). The lowermost part of unit B was dominated by hori- zontally diffuse-laminated sand and the upper parts by complex point bar sediments which include epsilon crossbedded ripple and dunebeds.

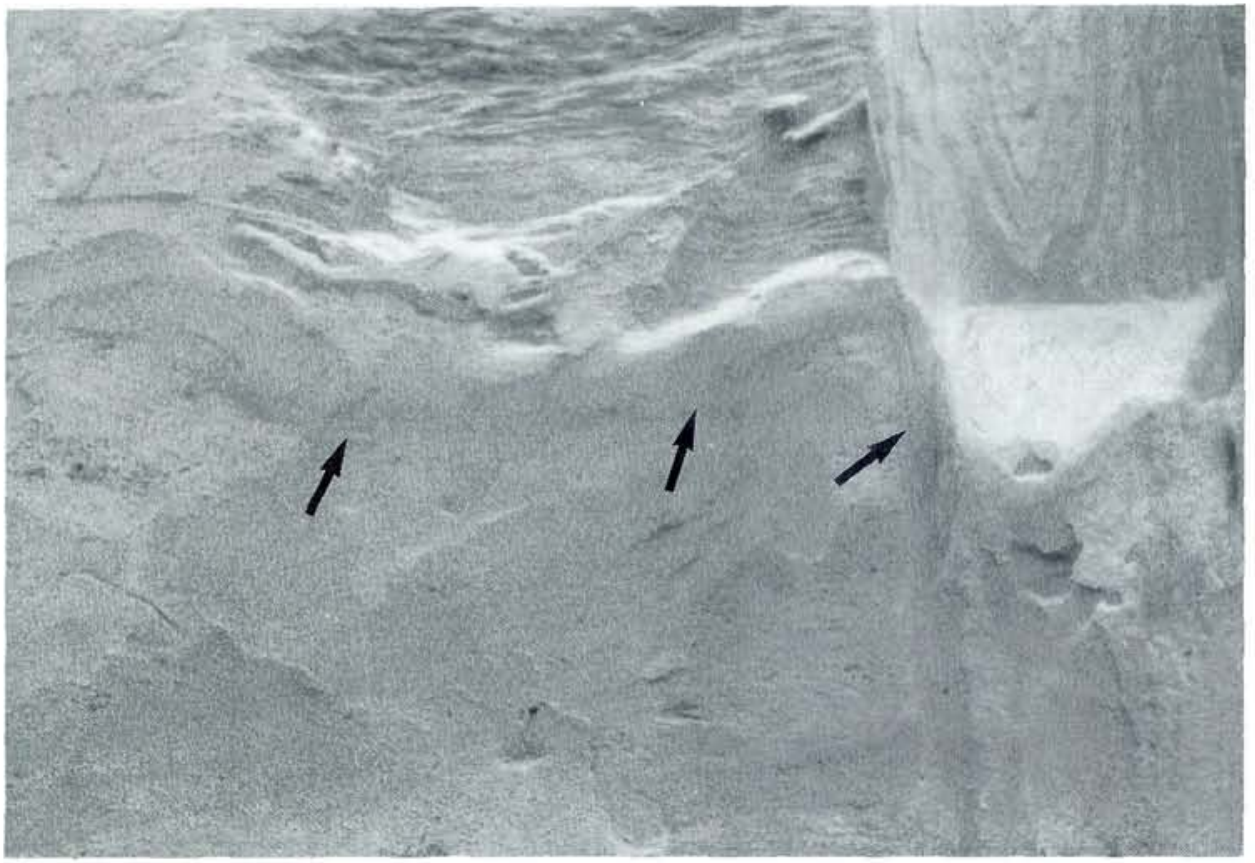

Fig. 5b: Detail of the Spanager structure. The arrows mark one particulary destinct apophyses. Note how this lamina continues from the cylinder out into the surrounding rippled sand. 
The point bar is distinctively channel side attached.

Unit $C$ is regarded as created as meander channel fill, characterized by the presence of dune cross bedded sets at the base and silt-clay drapes at the top. The drapes indicate that the meander channel was partly inactive at the time of deposition.

However, the channel became active again and small ripples as well as minor channels and fine grained drapes were produced (unit D).

Unit $\mathrm{E}$ is interpreted as channel scour and fills deposited in a meanderbelt, where pointbar growth caused the formation of lateral foresets with intrasets and planes of discontinuity.

The sequence has been divided into 3 cycles which are interpreted as reflecting anual discharge variatons. The anual discharge cycles ("megavarves") are 1) the unit A, 2) the unit B, C, D and 3) unit E, (Jensen, 1988).

\section{Description}

The vertical cylindrical structure of the Spanager gravel pit was minimum 2 meters in height and 25 centimeters in diameter, see fig. 4.. The top of the the structure was eroded and the base was unexposed.

Internally the Spananger vertical cylindrical structure consisted of concentric cylindrical sandy laminae almost circular in a true horizontal section, (fig. 5).

Generally the cylindrical laminae appeared more coarse grained at the center than in the outer parts and a close inspection revealed that the laminae were conical and vertically fining upwards.

The thickness of the laminae inside the cylinder varied from one to two millimeters. The thicker laminae were concentrated in the center and each laminae seemed to be well sorted. Outside the cylinder the laminae cut discordantly through the enclosing sand at an angle normal to the structures length, thus creating apophyses. At this point some apophyses became notably thicker up to several centimeters and generally also more finegrained (silt, clay). The apophyses showed lengths from 20 centimeters up to one meter.
The cylinder fill sediments seemed to be more or less a lithological copy of the enclosing sand.

Some of the outbranching laminae were cut by two population-sets of conjugated fault planes one being formed by a pressure from east and one initiated from south.

However no faultplanes were found cutting the sand-column itself.

\section{The Lynge structure}

\section{Stratigraphy}

The cylindrical structure at Lynge is found in glaciofluvial deposits which are overlain by till upto 6 meters in thickness. Till fabric analysis indicates an ice movement from the SSE and suggests that the till was deposited by the youngest Weichselian ice advance, the young Baltic advance (Houmark-Nielsen, 1987). The glaciofluvial deposits are therefore interpreted as local proglacial deposits of the Bælthav Readvance of the young Baltic Glaciation.

\section{Setting}

Sections upto 20 meters high have been exposed in the gravelpits at Lynge, NE-Sjælland. An overall coarsing upwards of the glaciofluvial sequence was observed although individual units displayed a fining upwards development (fig. 3).

In the lowermost part of the sequence a unit dominated by laminated silts beds and beds of small scale ripple laminated fine sand had a minimum thickness of 3 meters. The deposits are tentatively interpreted as belonging to a silt dominated braided river as envisaged by Rust (1978).

Above lies a unit upto 6 meters in thickness of coarse sand topped by laminated silts and fine sands and with 4 meters of parallel-laminated coarse sand in which the cylindrical structure was observed. The unit is thought to have been deposited very rapidly in a jøkulhlaup type situation (Miller, 1982). The upper parts of the sequence contain increasing amounts of gravel and the top consists of till deposited by the overriding ice.

A model for the area envisages an interlobate 


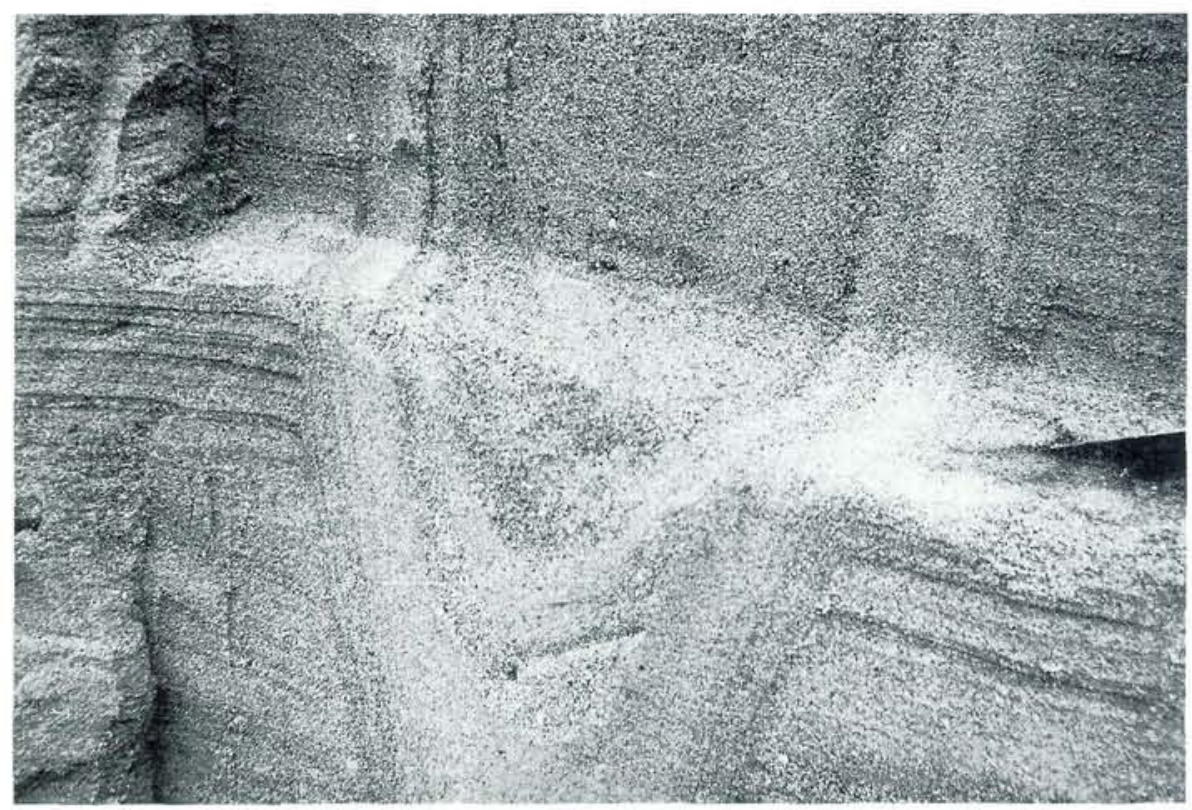

Fig. 6a: Detail of the Lynge Structure showing both horisontal and vertical sections. Note the sharp contact to the horisontally bedded sand. The diameter of the cylindrical structure is 40 centimeters.

sandur fan becoming increasingly constricted with the advance of the ice. Due to this increasing proximity a coarsening upwards sequence is produced.

\section{Description}

The cylindrical structure (fig. 6) was found in the parallel-laminated coarse sands of the supposed jøkulhlaup episode. Neither the top nor the base were exposed and thus only a minimum height of 2.5 meters can be given. In the exposed section there were only minor variations in diameter this being 40 to 45 centimeters. This contact to the enclosing sediment was very sharp and no disturbances of the deposits outside the structure were observed. Likewise no lateral injection structures (apophyses) were seen. Apparently there were little lithologically difference between the enclosing sediments and the cylinder fill. Internally the structure was filled by concentric cylindrical lamination which in horizontal section gives a concentric circular pattern and vertical lamination paired across the structure in a vertical section. Some sorting has occured in the structure with the coarsest fraction towards the center.

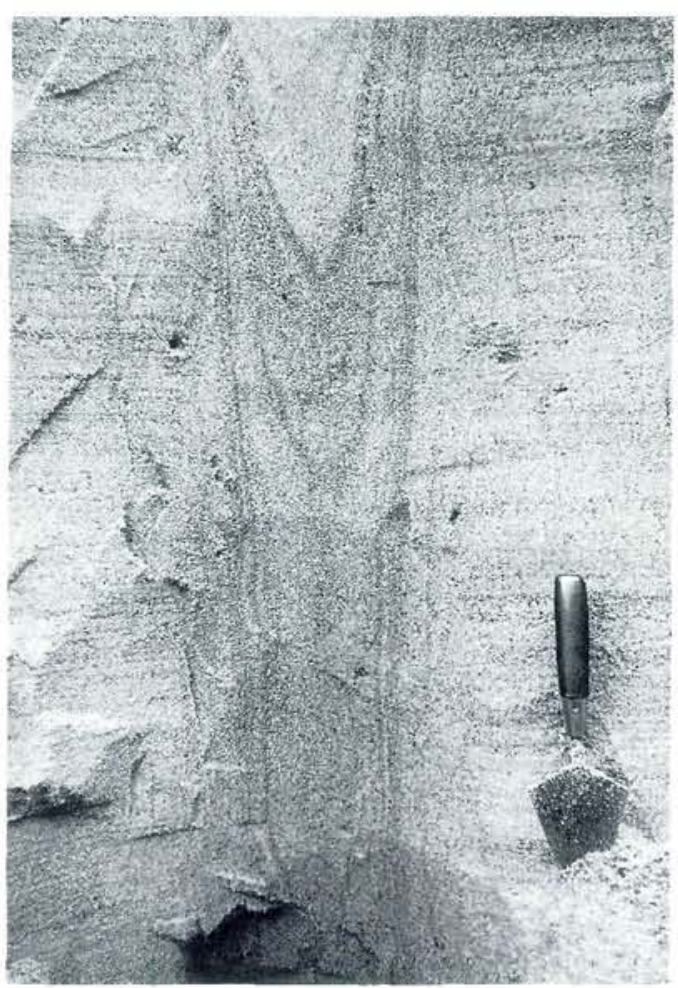

Fig. 6b: Detail of the Lynge Structure. Note the V-shaped cylindrical laminae in a oblique section. 


\section{Discussion}

On the grounds of paleogeographical conditions a number of previous suggestions for the origin of cylindrical structures can, in the present cases, immediately be rejected for example fossil tree trunk, biogenic escape structures and selective solution.

In the formation of cylindrical structures the shape and internal organisation must be considered as this can indicate whether the sediment emplaced in the structure is derived from above or below. Structures with a low height/width ratio and disorganised internal features are most likely formed by downward movements of sediment as in case fossil ice wedges and cryoturbation involutions.

The structures under consideration with a high height/width ratio and concentric, well sorted lamination are probably the result of emplacement from below.

The two examples from the danish Quaternary display well sorted, concentric lamination with inward coarsening in a true vertical section which indicates an aqueous depositional medium where an active grain size segregation was induced. As additional evidence for an upward movement of water and sediment mixture are the presence of apophysic continuation of the laminae into the surrounding sediments in the case of the Spanager structure.

It is therefore suggested that this kind of cylindrical structure is formed as large scale water escape structures which fall in the type B category of pillar according to the classification of Lowe (1975).

Having determined the water escape nature of the cylindrical structures three possibilities for the initiation of dewatering processes can be suggested, these being loading by ice, loading by sediments or a combination of both.

Some of the apophyses of the Spanager structure are clearly cut by conjugated fault planes which suggest "pre-faulting age" for the structure. The structure is therefore considered initiated by loading by overlying sediment whilst the conjugated faults are formed by at least two different ice advances. See Jensen (1985).

In case of the Lynge structure the interpretation of the sedimentary sequence suggests that dewatering under pressure was initiated by the sudden loading due to rapid deposition in the jøkulhlaup event. The fine grained silt dominated braided river deposits were in the course of perhaps little more than a day overlain by about 5 meters of additional sediment. Under such conditions pore water would be subjected to greatly increased pressure and on being released could form water escape structures.

The isolation of structures is puzzling as other associated water escape structures have not been observed nearby in the gravel pits. The structures are sited at points where the induced hydrostatic pressure was released in a single event without notably affecting the surrounding sediments or producing other "multible" water escape structures, e.q. dish structures or reconsolidation laminations.

We imagine a situation where the intergranular pore overpressure is confined and shield by an impermeable layer. At a weak point the liquified material penetrates the confining layer and pierces the overlying beds forming a vertical cylindrical conduit. The material carried in the conduit wil be a combination of the liquified sediment and sediments through which the conduit passes. There will be a tendency for the fine material to be carried upwards with the water out of the system as well as in some cases forming apophyses.

In short a three-bed model is suggested i) a lower mobilised bed, which is exposed to a hydrostatic pressure and shield by ii) an impermeable layer. The mobilised material from below escapes through a weak spot in the impermeable layer and travels through iii) the top layer creating a vertical cylindrical structure.

\section{Conclusion}

Apophyses of the Spanager vertical cylindrical structures show that an upward movement of water and sediment has occured creating water escape structure. Although apophyses are not present in the Lynge structure the same process is invoked. These types of cylindrical water escape structures can be expected in environments of rapid sedimentation dominated by sand and fines such as fluvial sandur and fluvial eskerine. The genetic model involves a three bed system:

i) a lower mobilised sandwater mixture con- 
fined by ii) an impermeable fine grained layer and iii) a rapidly sedimented top bed. The confined lower mobilised sand ruptures the impermeable layer and the top bed which loads the system and give rise to the formation of cylindrical water escape structure.

We suggest that our model may be favoured in different sedimentary environment where similar conditions prevail to explain the formation of vertical cylindrical structures.

\section{Acknowledgements}

We thank lic. scient. Lars Clemmesen for critically reading the manuscript.

\section{Dansk Sammendrag}

I Køge Ås, Spanager henh. i Lynge Sandurslette er der fundet vertikale vandundervigelsesstrukturer. I begge tilfælde er der tale om sandede rørformede strukturer med cylindriske svagt koniske laminæ. Rørerne er udad finende og laminæ er opad finende.

Fra Spanager strukturen, der er mindst 2 meter høj og 25 centimeter $\mathrm{i}$ diameter, breder de mest finkornede laminæ sig successivt lateralt ud $\mathrm{i}$ det omkringliggende pointbarresand som apofyser.

Lynge strukturen, der er mindst 2,5 meter høj og 40 til 45 centimeter i diameter, viser ikke apofysedannelse, men skarer skarpt igennem udeformeret horisontalt lamineret sand.

Da Spanager strukturens apofyser klart indicerer en sedimenttransport op og ud i værtssedimentet er denne ikke tolket som indsynkningsstruktur, iskile el. lign., men som en vandundvigelsesstruktur.

En sandsynlig dannelsesmodel for begge strukturer indebærer: 1) et nedre mobiliseret lag med højt hydrostatisk tryk, hvorover der findes 2) et impermeabelt dxklag, der adskiller det nedre lag fra 3) et øvre toplag, gennem hvilken vandundvigelsen sker.

Via et svagt sted $\mathbf{i}$ dæklaget sker der en vand- og sedimentundvigelse fra det nedre lag og op i det øvre toplag. De mest finkornede fraktioner transporteres op og ud mod siderne henh. evt. ud ad systemet eller - som i det sjaldne Spanager tilfalde - danner apofyser.

Ovenstående dannelsesmodel foreslås anvendt hvor forholdene er sammenlignelige med de $i$ artiklen beskrevne sedimentære miljøer og strukturer.

\section{References}

Arai, J. (1959) Cylindrical structures in Tertiary sediments of the Chichibu Basin, Saitama Prefecture, Japan. Bull. Chichibu. Mus. Nat. Hist. 9, 61-68.

Bromley, R. G., Curran, H. A., Frey, R. W., Gutschiick, R. C. and Suttner, L. J. (1975) Problems in interpreting unusually large burrows. In: Frey, R. W. (ed.) The study of trace fossils. Springer-Verlag, New York.

Dionne, J-C. (1973) Structures cylindriques verticales dans du Quaternaire a Arthabaska, Quebec. Sediment. Geol. 9, 53-63.

Dionne, J-C. and Laverdiere, C. (1972) Structure cylindrique verticale dans un depot meuble Quaternaire, au nord de Montreal, Quebec. Can. J. Earth sci. 9, 528-543.

Gabelman, J. W. (1955) Cylindrical structures in Permian (?) siltstones, Eagle County, Colerado. Jour. Geol. 63, 214227

Gulinck, M. (1949) Poches et pipes de sable dans le Landenien, pres de Havay. Bull. Soc. Belge Geol. 58, 403-413.

Hawley, J. E. and Hart, R. C. (1934) Cylindrical structures in sandstone. Bull. Geol. Soc. Am. 45, 1017-1034.

Houmark-Nielsen, M. (1987) Pleistocene Stratigraphy and Glacial History of the central part of Denmark. Bull. geol. Soc. Denmark. 36, 189 pp.

Jensen, J. P. (1985) Ȧssedimentation i det østlige Midtsjalland. Unpublished thesis, University of Copenhagen, $123 \mathrm{pp}$. (In danish).

Jensen, J. P. (1988) Lateral Accretion Features (Epsilon Crossbedding) and Point Bars in the Weichselian Køge Esker, East-Sjælland, Denmark. Bull. Geol. Soc. Denmark. 37, 11-19.

Kavanaugh, S. J. (1889) On modern concretions from the St. Lawrence. With remarks (by J. W. Dawson) on cylinders found in the Potsdam sandstone. Can. Rec. Sci. 3, 292-294.

Lowe, D. R. (1975) Water escape structures in coarse-grained sediments. Sedimentology 22, 157-204.

Lowe, D. R. and LoPiccolo (1974) The characteristics and origins of dish and pillow structures. J. Sedim. Petrol. 44, 484-501.

Miall, A. D. (1977) A Review of Braided River Depositional Environment. Earth. Sci. Revs. 13, 1-62.

Miall, A.D. (1978) Lithofacies types and Vertical Profile Models in Braided River Deposits: A Summary. In Fluvial Sedimentology, ed. Miall, A. D. Can. Soc. Petrol. Geol. Memoir 5, 597- 604.

Miller, J. G. (1982) Sedimentology of Glaciofluvial deposits, Lynge Area, (n.e. Sjoelland).Unpublished thesis, University of Copenhagen, $257 \mathrm{pp}$.

Rust, B. (1978) Depositional models for braided alluvium. In Miall, A. D. (ed) Fluvial sedimentology. Can. Soc. Petrol. Geol. Memoir 5, 605-625.

Schlee, J. S. (1963) Sandstone pipes of the Laguna area, New Mexico. J. Sedim. Petrol, 33, 112-123.

Simpson, G. G. (1935) Cylindrical structures in sandstone. (discussion). Bull. Geol. Soc. Am. 46, 2011-2014.

Simpson, G .G. (1936) Cylindrical structures in sandstone in Patagonia (abstr.) Proc. Geol. Soc. Am. p. 106 